\title{
Erratum: Multi-platform assessment of transcriptome profiling using RNA-seq in the ABRF next-generation sequencing study
}

Sheng Li, Scott W Tighe, Charles M Nicolet, Deborah Grove, Shawn Levy, William Farmerie, Agnes Viale, Chris Wright, Peter A Schweitzer, Yuan Gao, Dewey Kim, Joe Boland, Belynda Hicks, Ryan Kim, Sagar Chhangawala, Nadereh Jafari, Nalini Raghavachari, Jorge Gandara, Natàlia Garcia-Reyero, Cynthia Hendrickson, David Roberson, Jeffrey Rosenfeld, Todd Smith, Jason G Underwood, May Wang, Paul Zumbo, Don A Baldwin, George S Grills \& Christopher E Mason

Nat. Biotechnol. 32, 915-925 (2014); published online 24 August 2014; corrected after print 10 October 2014; doi:1038/nbt.2972

In the version of this article initially published, author Jeffrey Rosenfeld's middle initial "A" was omitted. The error has been corrected in the HTML and PDF versions of the article.

\section{Erratum: High-resolution metagenomics}

Eran Mick \& Rotem Sorek

Nat. Biotechnol. 32, 750-751 (2014); published online 7 August 2014; corrected after print 8 August 2014; doi:1038/nbt.2962

In the version of this article initially published, in the last paragraph, the sentence beginning, "However, the authors demonstrate that," should have ended with "...far fewer than the hundreds of samplings used here will suffice for many purposes." Instead of "...far fewer than the hundred of reads used here will suffice for many purposes." The error has been corrected in the HTML and PDF versions of the article.

\section{Erratum: Public biotech 2013-the numbers}

Stacy Lawrence \& Riku Lahteenmaki

Nat. Biotechnol. 32, 626-632 (2014); published online 8 July 2014; corrected after print 3 September 2014; doi:1038/nbt.2949

In the version of this article initially published, in Table 8, Enbrel (etanercept) was left off the table. It should have been in the number 2 spot in the table with 2013 revenue at $\$ 8,729$ million. In addition, the units of the last column, which are in $\$$ millions, were omitted in the title. The error has been corrected in the HTML and PDF versions of the article.

Corrigendum: Harmonizing standards for producing clinical-grade therapies from pluripotent stem cells

Peter W Andrews, Joy Cavanagro, Robert Deans, Ellen Feigel, Ed Horowitz, Armand Keating, Mahendra Rao, Marc Turner, Ian Wilmut \& Shinya Yamanaka

Nat. Biotechnol. 32, 724-726 (2014); published online 7 August 2014; corrected after print 10 October 2014; doi:1038/nbt.2973

In the version of this article initially published, two author names were misspelled: the correct names are Cavagnaro, not Cavanagro; Feigal not Feigel. In addition, the name for the Health Insurance Portability and Accountability Act (HIPAA) was given as Health Insurance Portability and Privacy Act (HIPPA). The errors have been corrected in the HTML and PDF versions of the article. 